\title{
Corrosion Inhibition by an Aqueous Extract of Phyllanthus Amarus
}

\author{
M. Sangeetha, ${ }^{*}{ }^{1}$ S. Rajendran, ${ }^{1,2}$ J. Sathiyabama, ${ }^{1}$ A. Krishnaveni, ${ }^{3}$ P. \\ Shanthy, ${ }^{3}$ N. Manimaran, ${ }^{3}$ B. Shyamaladevi ${ }^{4}$ \\ ${ }^{1} P G$ and Research Department of Chemistry, GTN Arts College, Dindigul-624005, \\ Tamil Nadu, India \\ ${ }^{2}$ Servite College of Education for Women, Thogaimalai-621313, Tamil Nadu, India. \\ ${ }^{3}$ Department of Chemistry, Yadava College, Madurai-625014, Tamil Nadu, India \\ ${ }^{4}$ Department of Chemistry, Vivekanandha Institute of Engineering and Technology for Women, \\ Elayampalayam, Tiruchengode, Tamil Nadu, India
}

Received 10 May 2011; accepted 10 December 2011

\begin{abstract}
The inhibition efficiency (IE) of phyllanthus amarus extract (PAE)- $\mathrm{Zn}^{2+}$ system, in controlling corrosion of carbon steel in an aqueous solution containing $60 \mathrm{ppm}$ of $\mathrm{Cl}^{-}$, has been evaluated by weight loss method. Weight loss study reveals that the formulation consisting of $2 \mathrm{~mL}$ of PAE and $25 \mathrm{ppm}$ of $\mathrm{Zn}^{2+}$ has $98 \%$ inhibition efficiency in controlling corrosion of carbon steel immersed in an aqueous solution containing $60 \mathrm{ppm}$ of $\mathrm{Cl}^{-}$. Synergistic parameters suggest that a synergistic effect exists between PAE and $\mathrm{Zn}^{2+}$. Polarization study reveals that this system functions as mixed type of inhibitor controlling the cathodic reaction and anodic reaction to an equal extend. AC impedance spectra reveal that a protective film is formed on the metal surface. The FTIR spectra reveal that the protective film consists of $\mathrm{Fe}^{2+}$-phyllanthus complex.
\end{abstract}

Keywords: corrosion inhibition, carbon steel, green inhibitor, environmentally friendly inhibitor, phyllanthus amarus.

\section{Introduction}

A number of heterocyclic compounds [1-3] have been reported as corrosion inhibitors and the screening of synthetic heterocyclic compounds is still being continued. Several other inorganic inhibitors such as zinc, chromate, polyphosphate, and nitrite were used as corrosion inhibitors. Also, molybdate, phosphates, phosphonocarboxylic acids and polymers were used as inhibitors,

\footnotetext{
* Corresponding author. E-mail address: sangeethamanirevathi@gmail.com
} 
along with metal ions such as $\mathrm{Zn}^{2+}$. Though many synthetic compounds showed good anticorrosive activity, most of them are highly toxic to both human beings and environment. These toxic effects and ecological problems associated with the discharge of such materials have resulted in the development of other efficient and environmentally acceptable inhibitors. Hence the recent trend is the search for environmental friendly inhibitors. Most of the natural products are non toxic, bio degradable and readily available in plenty. Various parts of the plants seeds, fruits, leaves, flowers, etc., have been used as corrosion inhibitors. Several studies have been published on the use of natural products as corrosion inhibitors $[4,5]$. Tannins are being used for protection of steel against corrosion in cooling water systems and in paints [6-8]. The biocidal and inhibitive effects of Azadirachta Indica have been studied on mild steel in fresh water [9]. The scale inhibition efficiencies of the aqueous extracts of plant materials namely Cordia latifolia, Eucalyptas and Jasmine auriculatum have been evaluated [10]. Corrosion inhibition by an aqueous extract of turmeric rhizome powder on carbon steel has been investigated by means of weight-loss, electrochemical polarization and impedance studies [11]. Corrosion inhibition has been studied with Eugenia jambolans [12], Androgaphis paniculata [13], Acacia Arabica [14]. Kliskic et al. have used the first neutral phenol sub fraction of the aqueous extract of rosemary leaves as corrosion inhibitor for the $\mathrm{Al}-\mathrm{Mg}$ alloy in a $3 \% \mathrm{NaCl}$ solution at $298 \mathrm{~K}$ [15]. Lawsonia extract has been used to inhibit corrosion of metals [16]. Corrosion inhibition of iron in hydrochloric acid solutions by naturally occurring henna has been investigated [17]. The corrosion inhibition efficiency of a caffeine- $\mathrm{Zn}^{2+}$ system on mild steel immersed in an aqueous solution containing $60 \mathrm{ppm}$ of chloride was investigated by weight loss study [18]. Aqueous extract of kalmegh (Andrographis paniculata) leaves has been used as green inhibitor [19]. Eco-friendly corrosion inhibitor - garcinia kola has been used to prevent corrosion of mild steel in $\mathrm{H}_{2} \mathrm{SO}_{4}$ solutions [20]. Inhibitory effects of ocinum tenuiplorum (Tulsi) have been investigated [21]. Anti-corrosive effect of raphia hookeri exudates gum-halide mixtures has been studied [22]. Ethanol extract of phyllanthus amarus green inhibitor has been used to prevent the corrosion of mild steel in $\mathrm{H}_{2} \mathrm{SO}_{4}$ [23]. Terminalia catappa extract has corrosion inhibitive properties [24].

There are several reviews on the use of plant extracts as corrosion inhibitors [25]. Recently, aqueous extract of cocos nucifera - coconut palm - petiole [26], fennel (foeniculum vulgare) essential oil [27], pericarp of the fruit of garcinia mangostana [28], natural fenugreek [29], ethanol extract of vernonia amygdalina[30] and ipomoea involcrata [31], have been used as corrosion inhibitors.

Phyllanthus amarus plant is bitter, febrifuge and antiseptic. It is useful in dropsy, jaundice, diarrhea, dysentery, intermittent fevers, diseases of urino-genital system, scabies ulcers and wounds.

The major ingredients of phyllanthus amarus are phyllanthin, hypophyllanthin, phyllanthusiin D, amarin, amarulone and amarinic acid [32,33]. Structure of phyllanthusiin $\mathrm{D}$ is shown in scheme 1. All of them have the following functional groups in common: $-\mathrm{OCH}_{3}, \mathrm{C}=\mathrm{O}, \mathrm{OH}$, ring oxygen and conjugated double bonds. 
The present work is under taken (i) to evaluate the inhibition efficiency (IE) of an aqueous extract of phyllanthus amarus in controlling the corrosion of carbon steel in an aqueous solution containing $60 \mathrm{ppm}$ of $\mathrm{Cl}^{-}$in the presence and absence of $\mathrm{Zn}^{2+}$; (ii) to examine the influence of biocides such as N-cetyl-N,N,Ntrimethylammonium bromide (CTAB) and sodium dodecyl sulphate (SDS), and the influence of $\mathrm{pH}$ and duration of immersion on the IE of the phyllanthus amarus extract; (iii) to analyse the protective film formed on the carbon steel by FTIR and UV-visible spectra; (iv) to understand the mechanistic aspects of corrosion inhibition by potentiodynamic polarization studies and AC impedance analysis.

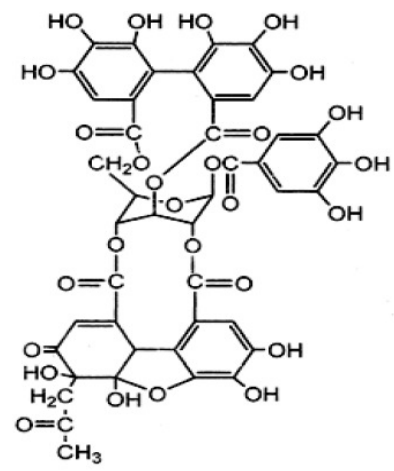

Scheme 1. Structure of phyllanthusiin D.

\section{Experimental}

\section{Preparation of phyllanthus amarus extract}

An aqueous extract of phyllanthus leaves was prepared by grinding $10 \mathrm{~g}$ of shade dried phyllanthus leaves, with distilled water, filtering the suspending impurities, and making up to $100 \mathrm{~mL}$. The extract was used as corrosion inhibitor in the present study.

\section{Preparation of the specimens}

Carbon steel specimens $(0.026 \% \mathrm{~S}, 0.06 \% \mathrm{P}, 0.4 \% \mathrm{Mn}, 0.1 \% \mathrm{C}$ and rest iron) of the dimensions $1.0 \times 4.0 \times 0.2 \mathrm{~cm}$ were polished to a mirror finish, degreased with trichloroethylene, and used for the weight-loss method and surface examination studies.

\section{Weight - loss method}

Carbon steel specimens were immersed in $100 \mathrm{~mL}$ of a solution containing 60 ppm of $\mathrm{Cl}^{-}$and various concentrations of the inhibitor in the presence and absence of $\mathrm{Zn}^{2+}$ for a period of 1 day. The weights of the specimens before and after immersion were determined using a balance, Shimadzu AY62 model. The inhibition efficiency (IE) was then calculated using the equation

$$
\mathrm{IE}=100[1-(\mathrm{W} 2 / \mathrm{W} 1)] \%
$$

where $\mathrm{W} 1=$ corrosion rate in absence of the inhibitor; $\mathrm{W} 2=$ corrosion rate in presence of the inhibitor. 


\section{Surface examination study}

The carbon steel specimens were immersed in various test solutions for a period of one day. After one day, the specimens were taken out and dried. The nature of the film formed on the surface of the metal specimen was analyzed by surface analysis techniques, such as FTIR and UV-visible reflectance spectroscopy, namely, fluorescence spectroscopy.

\section{Synergism parameters}

Synergism parameters are indications of the synergistic effect existing between two inhibitors.

Synergism parameters were calculated using the relation

$$
S_{\mathrm{I}}=1-\theta_{1+2} / 1-\theta^{\prime}{ }_{1+2}
$$

where $\theta_{1+2}=\left(\theta_{1}+\theta_{2}\right)-\left(\theta_{1} \times \theta_{2}\right)$, being $\theta_{1}=$ surface coverage of substance 1 and $\theta_{2}=$ surface coverage of substance 2. $\theta{ }^{1}{ }_{1+2}=$ combined surface coverage of substances 1 and 2. $\theta=$ surface coverage $=I E \% / 100$.

\section{Analysis of variance (F-Test)}

F-test was carried out to investigate whether the synergistic effect between CAE and $\mathrm{Zn}^{2+}$ was statistically significant.

\section{Potentiodynamic polarization study}

This study was carried out using a CHI 660A electrochemical impedance analyzer model. A three - electrode cell assembly was used. The working electrode used was carbon steel with $1 \mathrm{~cm} 2$ exposed area. A saturated calomel electrode (SCE) was used as reference electrode. A rectangular platinum foil was used as the counter electrode. Polarization curves were recorded after doing $i \mathrm{R}$ compensation. The parameters such as Tafel slopes, Icorr and Ecorr were calculated.

\section{AC impedance measurements}

A CHI 660A electrochemical impedance analyzer model was used to record AC impedance measurements. The cell set up was the same as that used for polarization measurements. The real part (Z') and imaginary part (Z') of the cell impedance were measured in ohms for various frequencies. The Rt (charge transfer resistance) and $\mathrm{C} d l$ (double layer capacitance) values were calculated.

\section{$U V$-visible spectra}

UV-visible spectra were recorded in an UV spectrod S-100 Analytic Jena spectrophotometer.

\section{FTIR spectra}

These spectra were recorded with a Perkin-Elmer 1600 spectrophotometer. The FTIR spectrum of the protective film was recorded by carefully removing the film mixing it with $\mathrm{KBr}$ and making the pellet. 


\section{Results and discussion}

\section{Analysis of results of weight - loss study}

The inhibition efficiency (IE) of an aqueous extract of phyllanthus amarus, in controlling corrosion of carbon steel in an aqueous solution containing $60 \mathrm{ppm}$ $\mathrm{Cl}^{-}$has been evaluated by weight loss method. The results are given in Table 1. It is seen from Table 1 that when the carbon steel is immersed in aqueous solution containing $60 \mathrm{ppm}$ of $\mathrm{Cl}^{-}$, the corrosion rate is $43.63 \mathrm{mdd}$. When $2 \mathrm{~mL}$ of phyllanthus amarus extract (PAE) are added, the corrosion rate is reduced to 18.32 mdd and the IE is found to be $58 \%$. Upon addition of various concentrations $(2,4,6$, and $8 \mathrm{~mL})$ of PAE, IE decreases. This is due to the fact that the complex $\left(\mathrm{Fe}^{2+}\right.$-active principle in PAE) formed on the metal surface dissolves and goes into solution. Similar observation has been made in the case of corrosion inhibition by Henna extract [34]. It is seen from Table 1 that when zinc is added to the PAE, the IE increases to a great extent. For example, when 25 ppm of $\mathrm{Zn}^{2+}$ are added to $2 \mathrm{~mL}$ of PAE, the IE increases from $58 \%$ to $98 \%$. This suggests that a synergistic effect exists between $\mathrm{Zn}^{2+}$ and the active principles present in PAE. However, it is observed that when the concentration of $\mathrm{Zn}^{2+}$ increases from $25 \mathrm{ppm}$ to $50 \mathrm{ppm}$, the IE slightly decreases. This may be due to the fact that, when the concentration of $\mathrm{Zn}^{2+}$ increases, the $\mathrm{Zn}^{2+}-\mathrm{PAE}$ complex formed is precipitated in the bulk of the solution. Hence PAE is not transported towards the metal surface. So the IE decreases.

Table 1. Corrosion rates (CR) of carbon steel immersed in an aqueous solution containing $60 \mathrm{ppm}$ of $\mathrm{Cl}^{-}$in the absence and presence of inhibitors and the inhibition efficiencies obtained by weight loss method. Inhibitors: phyllanthus amarus extract $(\mathrm{PAE})+\mathrm{Zn}^{2+}$. Period of immersion: 1 day.

\begin{tabular}{cccccccc}
\hline \multirow{2}{*}{$\mathrm{Cl}^{-} \mathrm{ppm}$} & $\begin{array}{c}\text { PAE } \\
\mathrm{mL}\end{array}$ & $\begin{array}{c}\mathrm{Zn}^{2+} \\
0 \mathrm{ppm}\end{array}$ & $\begin{array}{c}\mathrm{Zn}^{2+} \\
25 \mathrm{ppm}\end{array}$ & $\begin{array}{c}\mathrm{Zn}^{2+} \\
50 \mathrm{ppm}\end{array}$ & $\begin{array}{c}\mathrm{Zn}^{2+} \\
0 \mathrm{ppm}\end{array}$ & $\begin{array}{c}\mathrm{Zn}^{2+} \\
25 \mathrm{ppm}\end{array}$ & $\begin{array}{c}\mathrm{Zn}^{2+} \\
50 \mathrm{ppm}\end{array}$ \\
\hline 60 & 0 & 43.63 & 36.64 & 33.59 & -- & 16 & 23 \\
60 & 2 & 18.32 & 0.90 & 3.92 & 58 & 98 & 91 \\
60 & 4 & 20.94 & 2.18 & 3.92 & 52 & 95 & 91 \\
60 & 6 & 23.99 & 6.54 & 6.54 & 45 & 85 & 85 \\
60 & 8 & 41.84 & 8.28 & 9.16 & 4.1 & 81 & 79 \\
\hline
\end{tabular}

\section{Influence of duration of immersion on the inhibition efficiency of PAE $\mathrm{Zn}^{2+}$ system}

The influence of duration of immersion on the inhibition efficiency of the $\mathrm{Zn}^{2+}$ phyllanthus system is given in Table 2. It is observed that as the duration of immersion increases, the inhibition efficiency decreases. This is due to the fact that as the duration of immersion increases, the protective film formed on the metal surface is not able to withstand the attack of $\mathrm{Cl}^{-}$. The film is broken and hence the IE decreases. Similar observation was made with $\mathrm{Fe}^{2+}$ curcumin system 
[11], $\mathrm{Fe}^{2+}$-Henna leaves system [34] and pentanesulphonic acid - $\mathrm{Zn}^{2+}$ system [35].

Table 2. Influence of duration of immersion on the inhibition efficiency of PAE- $\mathrm{Zn}^{2+}$ system.

\begin{tabular}{lcccc}
\hline Immersion period, day & 1 & 3 & 5 & 7 \\
CR in the absence of the inhibitor, mdd & 43.63 & 31.51 & 21.81 & 21.94 \\
CR in the presence of the inhibitor, mdd & 0.90 & 15.43 & 12.86 & 15.35 \\
$\mathbb{E} \%$ & 98 & 51 & 41 & 30 \\
\hline
\end{tabular}

Influence of sodium dodecyl sulphate (SDS) on the IE of PAE - Zn ${ }^{2+}$ system

It is observed from Table 3 that as the concentration of SDS increases, the IE increases and then decreases and again increases. SDS is an anionic surfactant. It has biocidal activity also [36]. A micelle would have been formed at the minimum efficiency concentration. When more amount of SDS is added, SDS exists as monomer. These monomers are easily adsorbed on the metal surface. A protective film is formed. This prevents corrosion of metal [37]. It is observed that the formulation consisting of $2 \mathrm{~mL}$ of PAE $25 \mathrm{ppm}$ of $\mathrm{Zn}^{2+}$ and $250 \mathrm{ppm}$ of SDS has $95 \%$ corrosion IE. The biocidal nature of SDS is known [36]. Hence, if the biocidal study of the system (PAE- $\left.\mathrm{Zn}^{2+}-\mathrm{SDS}\right)$ is established in future, this formulation may find application in cooling water system, where corrosion of the metal is caused by aggressive ions and also by micro organisms present in cooling water.

Table 3. Influence of sodium dodecyl sulphate (SDS) on the inhibition efficiency of phyllanthus amarus $-\mathrm{Zn}^{2+}$ system.

\begin{tabular}{cccccc}
\hline $\begin{array}{c}\mathrm{Cl}^{-} \\
\mathrm{ppm}\end{array}$ & $\begin{array}{c}\mathrm{PAE} \\
\mathrm{mL}\end{array}$ & $\begin{array}{c}\mathrm{Zn}^{2+} \\
\mathrm{ppm}\end{array}$ & $\begin{array}{c}\text { SDS } \\
\text { ppm }\end{array}$ & CR mdd & IE \% \\
\hline 60 & 0 & 0 & 0 & 43.63 & - \\
60 & 2 & 25 & 50 & 5.67 & 87 \\
60 & 2 & 25 & 100 & 3.05 & 93 \\
60 & 2 & 25 & 150 & 3.92 & 91 \\
60 & 2 & 25 & 200 & 3.05 & 93 \\
60 & 2 & 25 & 250 & 2.18 & 95 \\
\hline
\end{tabular}

\section{Influence of $N$-Cetyl $N, N, N$-trimethyl ammonium bromide (CTAB) on the inhibition efficiency of PAE - $\mathrm{Zn}^{2+}$ system}

The influence of (CTAB) on the corrosion rates of carbon steel containing $\mathrm{Zn}^{2+}$ + PAE is tabulated in Table 4.

When various concentrations of $\mathrm{N}$-cetyl-N,N,N-trimethylammonium bromide (CTAB) are added to the inhibitor system, the inhibition efficiency decreases and reaches a minimum, and then increases. A micelle would have been formed at the minimum efficiency concentration [37, 38]. Afterwards the micelles would have been converted into monomers, which improved the inhibition efficiency. When more amount of CTAB is added, CTAB exists as monomer; these monomers are easily adsorbed on the metal surface. A protective film is formed. This prevents corrosion of metal. This can be explained as stated in the case of SDS. 
Table 4. Influence of N-cetyl N, N, N-trimethyl ammonium bromide (CTAB) on the inhibition efficiency of PAE - $\mathrm{Zn}^{2+}$ system.

\begin{tabular}{cccccc}
\hline $\begin{array}{c}\mathrm{Cl}^{-} \\
\mathrm{ppm}\end{array}$ & $\begin{array}{c}\mathrm{PAE} \\
\mathrm{mL}\end{array}$ & $\begin{array}{c}\mathrm{Zn}^{2+} \\
\mathrm{ppm}\end{array}$ & $\begin{array}{c}\mathrm{CTAB} \\
\mathrm{ppm}\end{array}$ & $\begin{array}{c}\mathrm{CR} \\
\mathrm{mdd}\end{array}$ & $\mathrm{IE} \%$ \\
\hline 60 & 0 & 0 & 0 & 43.63 & - \\
60 & 2 & 25 & 50 & 15.70 & 64 \\
60 & 2 & 25 & 100 & 28.35 & 35 \\
60 & 2 & 25 & 150 & 29.23 & 33 \\
60 & 2 & 25 & 200 & 14.83 & 66 \\
60 & 2 & 25 & 250 & 3.92 & 91 \\
\hline
\end{tabular}

Table 5. Influence of $\mathrm{pH}$ on the inhibition efficiency of phyllanthus amarus- $\mathrm{Zn}^{2+}$ system.

\begin{tabular}{cccccc}
\hline $\begin{array}{c}\mathrm{Cl}^{-} \\
\mathrm{ppm}\end{array}$ & $\begin{array}{c}\mathrm{PAE} \\
\mathrm{mL}\end{array}$ & $\begin{array}{c}\mathrm{Zn}^{2+} \\
\mathrm{ppm}\end{array}$ & $\mathrm{pH}$ & $\begin{array}{c}\mathrm{CR} \\
\mathrm{mdd}\end{array}$ & $\mathrm{IE} \%$ \\
\hline 60 & 0 & 0 & 6 & 45.38 & - \\
60 & 2 & 25 & 6 & 9.52 & 79 \\
60 & 0 & 0 & 7 & 43.63 & - \\
60 & 2 & 25 & 7 & 0.87 & 98 \\
60 & 0 & 0 & 8 & 41.26 & - \\
60 & 2 & 25 & 8 & 4.53 & 89 \\
\hline
\end{tabular}

\section{Influence of $\mathrm{pH}$ on IE of phyllanthus amarus- $\mathrm{Zn}^{2+}$ system}

It is seen from Table 5 that at $\mathrm{pH} 7$, the phyllanthus amarus (PAE) $(2 \mathrm{~mL})-\mathrm{Zn}^{2+}$ (25 ppm) (60 ppm) $\mathrm{Cl}^{-}$system has $98 \%$ IE. When $\mathrm{pH}$ is lowered to 6 by addition of dilute sulphuric acid, the IE decreased to $79 \%$. This is due to the fact that when the acid is added the protective film is broken by the aggressive $\mathrm{H}^{+}$ion present in the acid. When the $\mathrm{pH}$ is increased to 8 by addition of diluted sodium hydroxide solution, the IE increased to $89 \%$ (when compared to an acidic medium). This is due to the fact that the phenolic - $\mathrm{OH}$ groups would have been ionized to phenolate anion, $-\mathrm{O}^{-} \mathrm{Na}^{+}$. This helped anchoring of phenolic $\mathrm{O}^{-}$on the anodic sites of the metal surface effectively and hence IE increased at higher $\mathrm{pH}$ values. Similar observation has been observed in the case of corrosion inhibition by curcumin extract and by henna extract: as the value of $\mathrm{pH}$ is increased the corrosion inhibition efficiency also increased [34,35]. However this $89 \%$ IE in basic medium ( $\mathrm{pH} 8)$ is lower than the IE of $95 \%$ in neutral medium. This is due to the fact when $\mathrm{NaOH}$ is added, a portion of $\mathrm{Zn}^{2+}$ is precipitated as $\mathrm{Zn}(\mathrm{OH})_{2}$ in the bulk of the solution. Hence PAE is not effectively transported to the metal surface and hence the IE slightly decreases.

\section{Synergism parameters $\left(S_{I}\right)$}

Synergism parameters have been used to confirm the synergistic effect existing between two inhibitor systems [34,39]. Synergism parameters have been calculated for PAE- $\mathrm{Zn}^{2+}(25 \mathrm{ppm}$ and $50 \mathrm{ppm})$ systems. The results are given in Tables 6 and 7. It is observed that the synergism parameters are greater than 1. This confirms the synergistic effect existing between PAE $\mathrm{Zn}^{2+}$. It is also interesting to note that the values of $S_{\text {I }}$ are slightly smaller in the case of $50 \mathrm{ppm}$ of $\mathrm{Zn}^{2+}$ when compared with $25 \mathrm{ppm}$ of $\mathrm{Zn}^{2+}$. This is in agreement with the 
inhibition efficiencies obtained by weight loss method. Thus the values of synergism parameters give a quantitative value of synergism existing between the two inhibitors.

Table 6. Synergism parameters derived from inhibition efficiencies of phyllanthus amarus $-\mathrm{Zn}^{2+}$ system.

\begin{tabular}{cccc}
\hline \multirow{2}{*}{$\begin{array}{c}\text { PAE } \\
\mathrm{mL}\end{array}$} & $\begin{array}{c}c \\
\mathrm{Zn}^{2+}\end{array}$ & 25 & $\mathrm{~S}_{\mathrm{I}}$ \\
\cline { 2 - 3 } & $\mathrm{ppm}$ & $\mathrm{ppm}$ & \\
\hline 0 & - & 16 & - \\
2 & 58 & 98 & 17.64 \\
4 & 52 & 95 & 8.06 \\
6 & 45 & 85 & 3.08 \\
8 & 4.1 & 81 & 4.23 \\
\hline
\end{tabular}

Table 7. Synergism parameters derived from inhibition efficiencies of phyllanthus amarus $-\mathrm{Zn}^{2+}$ system.

\begin{tabular}{cccc}
\hline \multirow{2}{*}{$\begin{array}{c}\text { PAE } \\
\mathrm{mL}\end{array}$} & $\begin{array}{c}0 \\
\mathrm{Zn}^{2+}\end{array}$ & $\begin{array}{c}50 \\
\mathrm{ppm}\end{array}$ & $\mathrm{spm}$ \\
& $\mathrm{s}$ I & \\
\hline 0 & - & 23 & - \\
2 & 58 & 91 & 3.59 \\
4 & 52 & 91 & 4.10 \\
6 & 45 & 85 & 2.82 \\
8 & 4.1 & 79 & 3.52 \\
\hline
\end{tabular}

\section{Analysis of F-values (analysis of variance ANOVA)}

Analysis of variance has been used to established if the synergistic effect existing the between two inhibitor systems is statistically significant [40,41]. The F-value calculated for PAE- $\mathrm{Zn}^{2+}(25 \mathrm{ppm})$ system is 60.68 (Table 8). This is greater than the critical F-value (5.99) for 1,6 degrees of freedom at 0.05 level of significance. Hence it is concluded that the synergistic effect existing between $25 \mathrm{ppm}$ of $\mathrm{Zn}^{2+}$ and various concentrations of PAE is statistically significant.

The F-value calculated for PAE- $\mathrm{Zn}^{2+}(50 \mathrm{ppm})$ system is 13.93 (Table 9). This is greater than the critical F-value (5.32) for 1,6 degrees of freedom at 0.05 level of significance. Hence it is concluded that the synergistic effect existing between 50 ppm of $\mathrm{Zn}^{2+}$ and various concentrations of PAE is statistically significant.

Table 8. Distribution of F-value between the inhibition efficiencies of various concentrations of phyllanthus $\left(0 \mathrm{ppm} \mathrm{Zn}^{2+}\right)$ and the inhibition efficiencies of

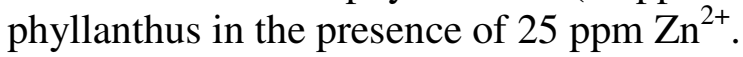

\begin{tabular}{cccccc}
\hline $\begin{array}{c}\text { Source of } \\
\text { variance }\end{array}$ & $\begin{array}{c}\text { Sum of } \\
\text { squares }\end{array}$ & $\begin{array}{c}\text { Degree of } \\
\text { freedom }\end{array}$ & Mean square & F - value & $\begin{array}{c}\text { Level of } \\
\text { significance of } F\end{array}$ \\
\hline $\begin{array}{c}\text { Between } \\
\text { samples } \\
\begin{array}{c}\text { Within } \\
\text { samples }\end{array}\end{array}$ & 4994 & 1 & 4994 & 60.68 & $\mathrm{p}>0.05$ \\
\hline
\end{tabular}


Table 9. Distribution of F-value between the inhibition efficiencies of various concentrations of phyllanthus $\left(0 \mathrm{ppm} \mathrm{Zn}^{2+}\right)$ and the inhibition efficiencies of phyllanthus in the presence of $50 \mathrm{ppm} \mathrm{Zn}^{2+}$.

\begin{tabular}{cccccc}
\hline $\begin{array}{c}\text { Source of } \\
\text { variance }\end{array}$ & $\begin{array}{c}\text { Sum of } \\
\text { squares }\end{array}$ & $\begin{array}{c}\text { Degree of } \\
\text { freedom }\end{array}$ & Mean square & F - value & $\begin{array}{c}\text { Level of } \\
\text { significance of } F\end{array}$ \\
\hline $\begin{array}{c}\text { Between } \\
\text { samples }\end{array}$ & 1091.38 & 1 & 1091.38 & 13.93 & $\mathrm{p}>0.05$ \\
$\begin{array}{c}\text { Within } \\
\text { samples }\end{array}$ & 470.15 & 6 & 78.36 & & \\
\hline
\end{tabular}

\section{Analysis of polarization curves}

Polarization study has been used to detect the formation of protective film on the metal surface [42-49]. When a protective film is formed on the metal surface, the linear polarization resistance (LPR) increases and the corrosion current (Icorr) decreases. The potentiodynamic polarization curves of carbon steel immersed in various test solutions are shown in Fig.1(a) and (b). The corrosion parameters,

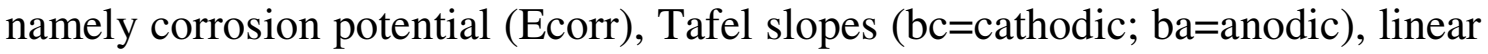
polarization resistance (LPR) and corrosion current (Icorr), are given in Table 10. When carbon steel is immersed in an aqueous solution containing $60 \mathrm{ppm} \mathrm{Cl}^{-}$, the corrosion potential is $-586 \mathrm{mV}$ vs. SCE. The formulation consisting of $2 \mathrm{~mL}$ of phyllanthus amarus extract (PAE) and $25 \mathrm{ppm}$ of $\mathrm{Zn}^{2+}$ shifts the corrosion potential to $-604 \mathrm{mV}$ vs. SCE. This suggests that the reaction is predominantly cathodically controlled.The LPR value increases from $23589 \mathrm{ohm} \mathrm{cm}^{2}$ to 67322 $\mathrm{ohm} \mathrm{cm}^{2}$. This suggests that a protective film is formed on the metal surface. Further the corrosion current decreases from $1.748 \times 10^{-6} \mathrm{~A} / \mathrm{cm}^{2}$ to $0.5071 \times 10^{-6}$ $\mathrm{A} / \mathrm{cm}^{2}$. The IE calculated from corrosion current is $71 \%$. This value is lower than the IE obtained by weight loss method $(98 \%)$. The discrepancy may be explained by the fact that in electrochemical process, the instantaneous corrosion current is measured. However, in the case of the weight loss method, IE is calculated after a long time. The protective film formed is strengthened as the duration of immersion increases.

In presence of inhibitors, the cathodic and anodic Tafel slopes are more or less equal. This indicates that the formulation consisting of PAE and $\mathrm{Zn}^{2+}$ functions as a mixed type inhibitor controlled by both the cathodic and anodic reactions to an equal extend. However the cathodic Tafel slope is slightly higher. This is reflected in the shift of corrosion potential to the cathodic side. 


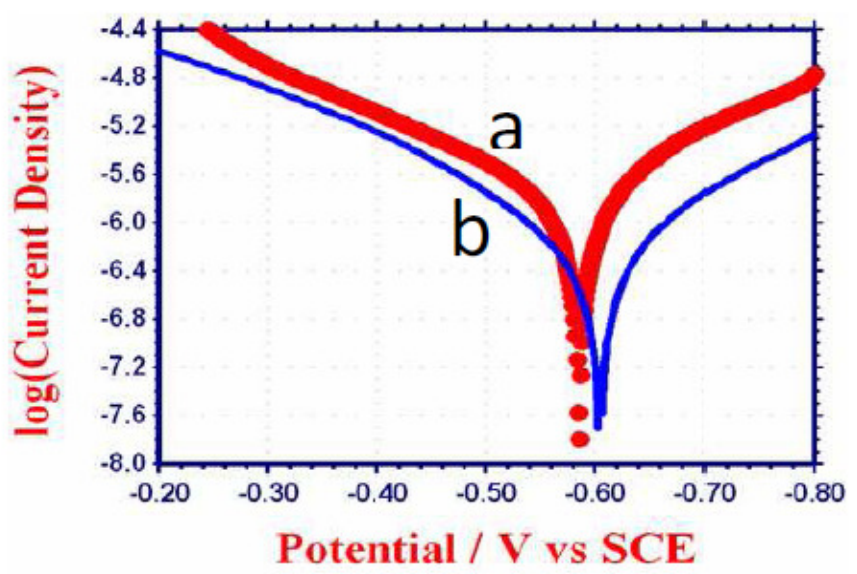

Figure 1. Polarization curves of carbon steel immersed in various test solutions. (a) $\mathrm{Cl}^{-}$ 60 ppm; (b) $\mathrm{Cl}^{-} 60 \mathrm{ppm}+\mathrm{PAE}(2 \mathrm{~mL})+\mathrm{Zn}^{2+} 25 \mathrm{ppm}$.

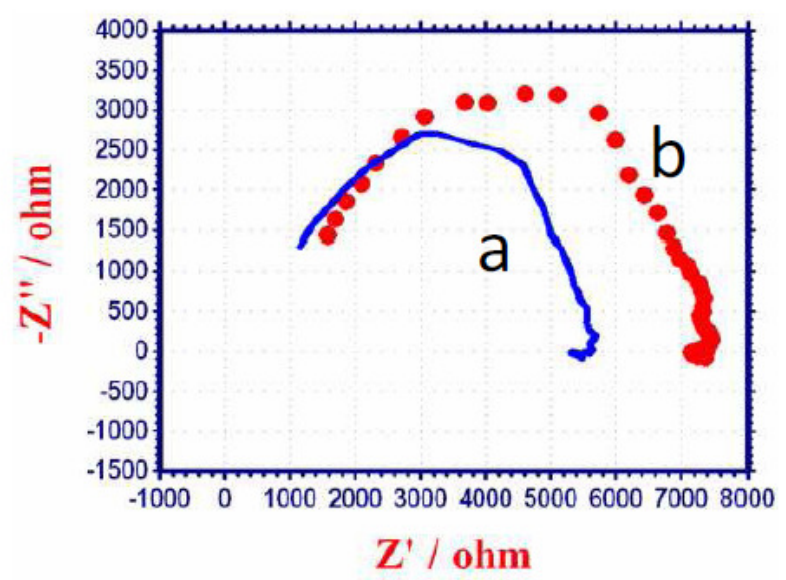

Figure 2. AC impedance spectra of carbon steel immersed in various test solutions (Nyquist plots). (a) $\mathrm{Cl}^{-} 60 \mathrm{ppm}$; (b) $\mathrm{Cl}^{-} 60 \mathrm{pm}+\mathrm{PAE}(2 \mathrm{~mL})+\mathrm{Zn}^{2+} 25 \mathrm{ppm}$.

Table 10. Corrosion parameters of carbon steel immersed in phyllanthus amarus extract obtained from polarization study.

\begin{tabular}{|c|c|c|c|c|c|}
\hline System & $\begin{array}{l}\mathrm{E}_{\text {corr }} \mathrm{mV} \\
\text { vs. SCE }\end{array}$ & $\begin{array}{c}\mathrm{b}_{\mathrm{c}} \\
\mathrm{mV} / \mathrm{dec} \text { de }\end{array}$ & $\mathrm{b}_{\mathrm{a}} \mathrm{mV} /$ decade & $\begin{array}{c}\text { LPR } \\
\mathrm{ohm} \mathrm{cm}^{2}\end{array}$ & $\begin{array}{c}\mathrm{I}_{\text {corr }} \\
\mathrm{A} / \mathrm{cm}^{2}\end{array}$ \\
\hline $\mathrm{Cl}^{-} 60 \mathrm{ppm}$ & -586 & 174 & 209 & 23589 & $1.748 \times 10^{-6}$ \\
\hline $\begin{array}{l}\mathrm{Cl}^{-} 60 \mathrm{ppm}+ \\
\mathrm{PAE}(2 \mathrm{~mL})+ \\
\mathrm{Zn}^{2+}(25 \mathrm{ppm})\end{array}$ & -604 & 158 & 155 & 67322 & $0.5071 \times 10^{-6}$ \\
\hline
\end{tabular}

\section{Analysis of AC impedance spectra}

$\mathrm{AC}$ impedance spectra have been used to detect the formation of a film on the metal surface. If a protective film is formed, the charge transfer resistance increases and the double layer capacitance value decreases [42]. The AC impedance spectra of carbon steel immersed in various solutions are shown in Fig. 2 (Nyquist plot). The AC impedance parameters, namely, charge transfer resistance $(\mathrm{Rt})$ and double layer capacitance $(\mathrm{Cdl})$ are given in Table 11. When 
carbon steel is immersed in aqueous solution containing $60 \mathrm{ppm}^{-}$, the Rt value

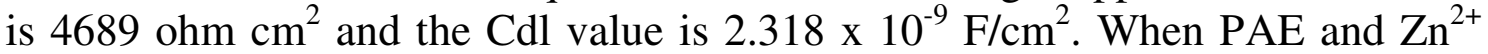
are added, the Rt value increases from $4689 \mathrm{ohm}^{2}$ to $6073 \mathrm{ohm} \mathrm{cm}^{2}$ and Cdl decreases from $2.318 \times 10^{-9} \mathrm{~F} / \mathrm{cm}^{2}$ to $1.789 \times 10^{-9} \mathrm{~F} / \mathrm{cm}^{2}$. This suggests that a protective film is formed on the surface of the metal. This accounts for the very high IE of PAE- $\mathrm{Zn}^{2+}$ system. Further there is increase in impedance, $\log (\mathrm{Z} / \mathrm{ohm})$, value from 3.736 to 3.869 (derived from Bode plot Fig.3a, Fig.3b).

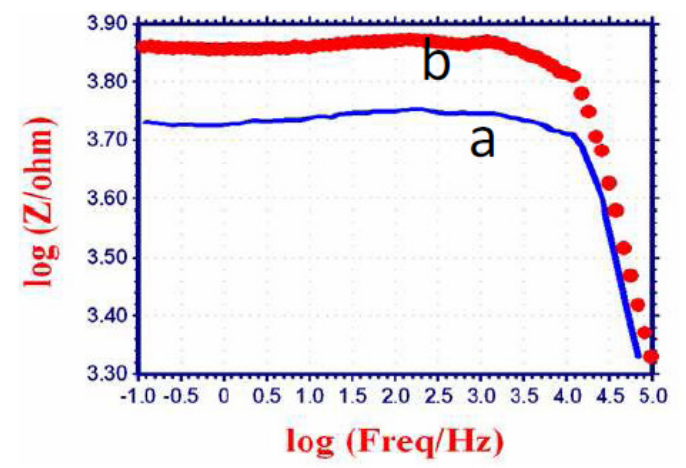

Figure 3a. AC impedance spectra of carbon steel immersed in various test solutions (Impedance-Bode plots). (a) $\mathrm{Cl}^{-} 60 \mathrm{ppm}$; (b) $\mathrm{Cl}^{-} 60 \mathrm{pm}+\mathrm{PAE}(2 \mathrm{~mL})+\mathrm{Zn}^{2+} 25 \mathrm{ppm}$.

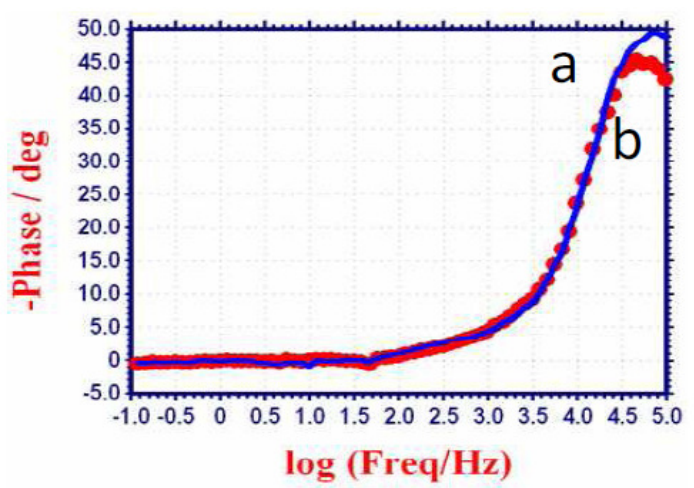

Figure 3b. AC impedance spectra of carbon steel immersed in various test solutions (phase-Bode plots). (a) $\mathrm{Cl}^{-} 60 \mathrm{ppm}$; (b) $\mathrm{Cl}^{-} 60 \mathrm{pm}+\mathrm{PAE}(2 \mathrm{~mL})+\mathrm{Zn}^{2+} 25 \mathrm{ppm}$.

Table 11. Corrosion parameters of carbon steel immersed in phyllanthus amarus extract, obtained from AC impedance spectral study.

\begin{tabular}{|c|c|c|c|}
\hline \multirow[b]{2}{*}{ System } & \multicolumn{2}{|c|}{ Nyquist plot } & \multirow{2}{*}{$\begin{array}{c}\text { Bode plot } \\
\text { Impedance value } \\
\log (\mathrm{z} / \mathrm{ohm})\end{array}$} \\
\hline & $\begin{array}{c}\mathrm{Rt} \\
\mathrm{ohm} \mathrm{cm}\end{array}$ & $\begin{array}{c}\mathrm{Cdl} \\
\mathrm{F} / \mathrm{cm}^{2}\end{array}$ & \\
\hline $\mathrm{Cl}^{-} 60 \mathrm{ppm}$ & 4689 & $2.318 \times 10^{-9}$ & 3.736 \\
\hline $\begin{array}{l}\mathrm{Cl}^{-} 60 \mathrm{ppm}^{2} \mathrm{PAE}(2 \\
\mathrm{mL})+\mathrm{Zn}^{2+}(25 \mathrm{ppm})\end{array}$ & 6073 & $1.789 \times 10^{-9}$ & 3.869 \\
\hline
\end{tabular}

\section{Analysis of $U V$-visible spectra}

The UV-visible absorption spectrum of an aqueous solution of PAE and $\mathrm{Fe}^{2+}$ (freshly prepared $\mathrm{FeSO} 4.7 \mathrm{H}_{2} \mathrm{O}$ solution) is shown in (Fig. 4). Peaks appear at 217,260 and $310 \mathrm{~nm}$. This is due to $\mathrm{Fe}^{2+}$-PAE complex formed in solution. The $\mathrm{UV}$-visible reflectance spectrum of the film formed on the metal surface after immersion in a solution containing $60 \mathrm{ppm} \mathrm{Cl}^{-}, 2 \mathrm{~mL}$ of PAE and $25 \mathrm{ppm}$ of 
$\mathrm{Zn}^{2+}$, is shown in (Fig. 5). Peaks appear at 217, 260 and $310 \mathrm{~nm}$. This matches with the $\mathrm{Fe}^{2+}$-PAE complex in solution. Hence it is confirmed that the protective film consists of $\mathrm{Fe}^{2+}$-PAE complex [50,51].

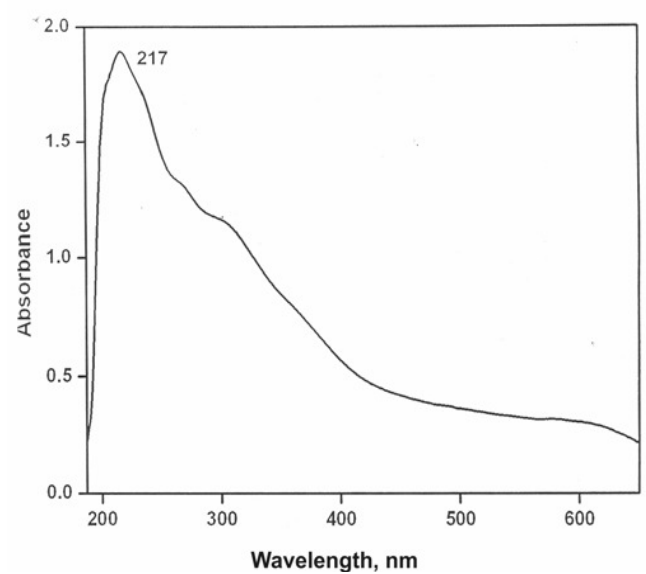

Figure 4. UV-visible absorption spectrum of an aqueous solution of PAE and $\mathrm{Fe}^{2+}$.

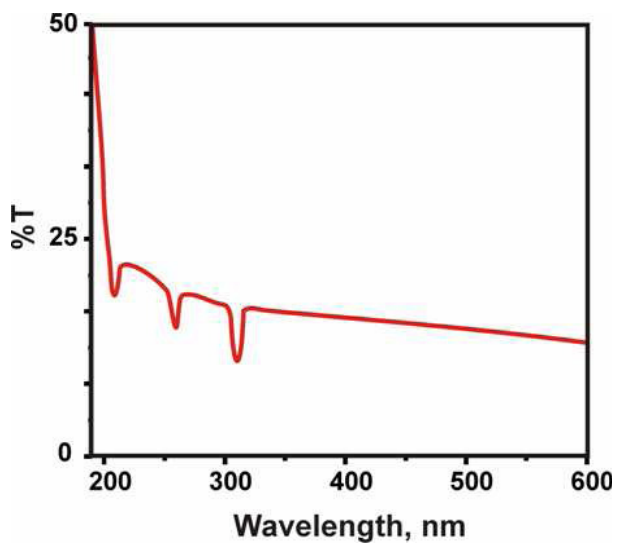

Figure 5. UV-visible reflectance spectrum of the metal after immersion in a solution containing $\mathrm{Cl}^{-} 60 \mathrm{ppm}, \mathrm{PAE}(2 \mathrm{~mL})$ and $\mathrm{Zn}^{2+} 25 \mathrm{ppm}$.

\section{Analysis of FTIR spectra}

The active principle in an aqueous extract of phyllanthus amarus is phyllanthusiin D (Scheme 1).

A few drops of an aqueous extract of phyllanthus were dried on a glass plate. A solid mass was obtained. Its FTIR spectrum is shown in Fig.6. The $\mathrm{C}=\mathrm{O}$ stretching frequency appears at $1606 \mathrm{~cm}^{-1}$. The $\mathrm{OH}$ stretching frequency appears at $3446 \mathrm{~cm}^{-1}$. The band due to conjugated double bonds appears at $3727 \mathrm{~cm}^{-1}$. The peak at $1112 \mathrm{~cm}^{-1}$ is due to ring oxygen atom. Thus the structure of phyllanthusiin-D is confirmed by FTIR spectrum [52].

The FTIR spectrum of the protective film formed on the surface of the metal after immersion in the solution containing $60 \mathrm{ppm}^{-1} \mathrm{Cl}^{-} 25 \mathrm{ppm}$ of $\mathrm{Zn}^{2+}$, and 2 $\mathrm{mL}$ of phyllanthus extract is shown in Fig.7. It is found that the phenolic $-\mathrm{OH}$ stretch has shifted from $3446 \mathrm{~cm}^{-1}$ to $3418 \mathrm{~cm}^{-1}$. The band due to conjugated double bonds shifts from $3727 \mathrm{~cm}^{-1}$ to $3726 \mathrm{~cm}^{-1}$. Ring oxygen atom stretching frequency has shifted from $1112 \mathrm{~cm}^{-1}$ to $1118 \mathrm{~cm}^{-1}$. The $\mathrm{C}=\mathrm{O}$ stretching frequency has shifted from $1606 \mathrm{~cm}^{-1}$ to $1612 \mathrm{~cm}^{-1}$. 


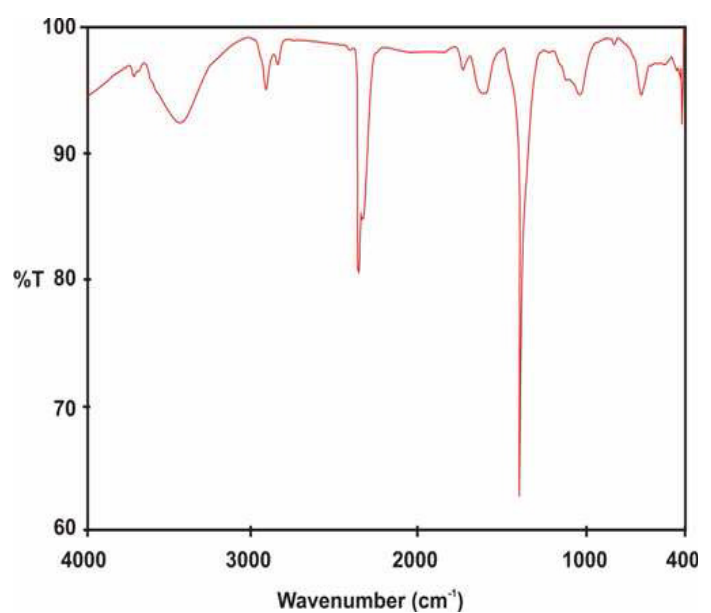

Figure 6. FTIR spectrum of pure PAE.

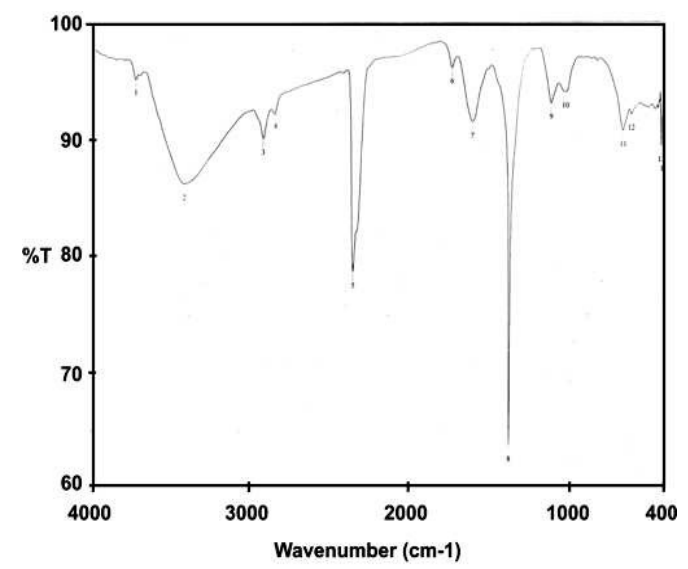

Figure 7. FTIR spectrum of the film formed on carbon steel surface after immersion in a solution containing $\mathrm{Cl}^{-} 60 \mathrm{ppm}+\mathrm{PAE}(2 \mathrm{~mL})+\mathrm{Zn}^{2+} 25 \mathrm{ppm}$.

This confirms the presence of $\mathrm{Fe}^{2+}$-phyllanthus extract complex on the metal surface. $\mathrm{Fe}^{2+}$ has coordinated with the $\mathrm{O}$-atom of the $-\mathrm{OH}$ group, $\mathrm{C}=\mathrm{O}$ group and the ring oxygen atom. These shifts confirm the formation of $\mathrm{Fe}^{2+}$ - phyllanthus complex on the anodic sites of the metal surface. The formation of $\mathrm{Fe}^{3+}$ phyllanthus amarus complex cannot be ruled out. The peak at $1384 \mathrm{~cm}^{-1}$ is due to $\mathrm{Zn}(\mathrm{OH})_{2}$ formed on the cathodic sites of the metal surface [52,53].

\section{Conclusions}

The inhibition efficiency (IE) of phyllanthus amarus extract (PAE) $-\mathrm{Zn}^{2+}$ system in controlling corrosion of carbon steel in an aqueous solution containing $60 \mathrm{ppm}$ of $\mathrm{Cl}^{-}$has been evaluated by weight loss method. The present study leads to the following conclusions.

Weight loss study reveals that the formulation consisting of $2 \mathrm{~mL}$ of PAE and 25 ppm of $\mathrm{Zn}^{2+}$ has $98 \%$ inhibition efficiency in controlling corrosion of carbon steel immersed in an aqueous solution containing $60 \mathrm{ppm}$ of $\mathrm{Cl}^{-}$.

Synergistic parameters suggest that a synergistic effect exists between PAE and $\mathrm{Zn}^{2+}$. 
Polarization study reveals that this system functions as a mixed type inhibitor, controlling the cathodic reaction and anodic reaction to an equal extent.

AC impedance spectra reveal that a protective film is formed on the metal surface.

The FTIR spectra reveal that the protecting film consists of $\mathrm{Fe}^{2+}$-phyllanthus amarus (active ingredient) complex.

\section{References}

1. F. Bentiss, M. Traisnel, M. Lagrenee, Corros. Sci. 42 (2000) 127.

2. S.T. Arab, E.A. Noor, Corrosion. 49 (1993) 122.

3. H. Luo, Y.C. Guan, K.N. Han, Corrosion 54 (1988) 721.

4. K. Srivastava, P. Srivastava, Br. Corros. J. 16 (1981) 221.

5. $\quad$ R.M. Saleh, A.A. Ismail, A.A. El Hosary, Br.Corros. J. 16 (1982) 131.

6. A.J. Saevell, J. Oil. Col. Chem. Assn. 61 (1978) 439.

7. E. Knowles, T. White, J. Oil. Col. Chem. Assn. 41 (1958) 10.

8. T.K. Ross, R.A. Francis, Corros. Sci. 18 (1978) 351.

9. M. Manimegalai, P. Rajeswari, S. Mohanam, S. Maruthamuthu, N. Palaniswamy, "Biocidal and Inhibition effect of Naturally occurring Substance - Azadiracta Indica in Fresh Water," Proc. of 10th National Congress on Corrosion Control, held Sept. 6-8 (Karaikudi, India: National Corrosion Council of India (2000)) 153.

10. I.H. Farooqui, M.A. Quraishi, "Breakthroughs in scale and deposit Control," Proc. of Industrial Corrosion Causes and Mitigation CORCON 2000, vol.2, held Nov.20-23 (Mumbai, India: Quest publication (2000)) 103.

11. S. Rajendran, S. Shanmugapriya, T. Rajalakshmi, A.J. Amalraj, Corrosion $61(2005) 685$.

12. A.S. Verma, G.N. Mehta, Trans. SAEST. 32 (1988) 4.

13. G.O. Avwiri, F.O. Igho, Mater. Lett. 57 (2003) 3705.

14. A.S. Verma, G.N. Mehta, Bull. Electrochem. 15 (1999) 67.

15. M. Kliskic, J. Radosevic, S. Gudic, V. Katalinic, J. Appl. Electrochem. 30 (2000) 823.

16. A.Y.E. Etre, M. Abdullah, Z.E.E. Tantawy, Corros. Sci. 47 (2005) 385.

17. A. Chetouani, B. Hammouti, Bull. Electrochem. 19 (2003) 23.

18. S. Rajendran, S. Vaibhavi, N. Anthony, D.C. Trivedi, Corrosion 59 (2003) 529.

19. A. Singh, V.K. Singh and M.A. Quraishi, Int. J. Corros. (2010) 10.

20. P.C. Okafor, V.I. Osabar, E.E. Ebenso, Pigment Resin Tech. 36 (2007) 299305.

21. S.K. Sharma, A. Mudhoo, G. Jain, J. Sharma, Rasayan J. Chem. 2 (2009) 332-339.

22. S.A. Umoren, E.E. Ebenso, Pigment Resin Tech. 37 (2008) 173-182.

23. N.O. Eddy, Port. Electrochim. Acta 27 (2009) 579-589.

24. N.O. Eddy, A. Patricia, Ekwelmemgbo, P.A.P.Mamza, Green Chem. Lett. Rev. 2 (2009) 223-231. 
25. M. Sangeetha, S. Rajendran, T.S. Muthumegala, A. Krishnaveni, Zastita Materijala 52 (2011) 3-19.

26. P.R. Vijayalakshmi, R. Rajalakshmi, S. Subhashini, Port. Electrochim. Acta 29 (2011) 9-21.

27. N. Lahhit, A. Bouyanzer, J.-M. Desjobert, B. Hammouti, R. Salghi, J. Costa, C. Jama, F. Bentiss, L. Majidi, Port. Electrochim. Acta 29 (2011) 127-138.

28. K.P.V. Kumar, M.S.N. Pillai, G.R. Thusnavis, Port. Electrochim. Acta, 28 (2010) 373-383.

29. A. Bouyanzer, B. Hammouti, L. Majidi, B. Haloui, Port. Electrochim. Acta 28 (2010) 165-172.

30. A.O. Odiongenyi, S.A. Odoemelam, N.O. Eddy, Port. Electrochim. Acta 27 (2009) 33-45.

31. I.B. Obot, N.O. Obi-Egbedi, Port. Electrochim. Acta 27 (2009) 517-524.

32. Indian Medicinal Plants, A Compendium of 500 Species, Orient Longman Ltd., Madras, 4 (1995) 252-255.

33. L.Y. Foo, Phytochemistry 33 (1993) 487-491.

34. S. Rajendran, M. Agasta, R. Bama Devi, B. Shyamala Devi, K. Rajam, J. Jeyasundari, Zastita Materijala 50 (2009).

35. C. Mary Anbarasi, Susai Rajendran, J. Electrochem. Soc. India 60 (2011) 115-122.

36. N. Antony, H.B. Sherine, S. Rajendran, Port. Electrochim. Acta 28. (2010) 1-4.

37. P. Shanthy, P. Rengan, A.T. Chelvan, K. Rathika, S. Rajendran, Indian J. Chem. Tech. 16 (2009) 328-33.

38. S. Rajendran, B.V. Apparao, N. Palanisamy, Bull. Electrochem. 13 (1997) 441.

39. H.B. Sherine, A.J.A. Nasser, S.Rajendran, J. Electrochem. Soc. India 58 (2009) 30-36.

40. S.A. Kanimozhi, S. Rajendran, Arabian J. Sci. Eng. 34 (2009) 37-47.

41. B. Sherine, A.J.A. Nasser, S. Rajendran, Int. J. Eng. Sci. Tech. 2 (2010) 341-357.

42. Y. Yesu Thangam, M. Kalanith, C. Mary Anbarasi, S. Rajendran, The Arabian J. Sci. Eng. 34 (2009) 49-60.

43. J. Sathiyabama, S. Rajendran, J.J. Sundari, B. Shyamaladevi, J. Eng. Sci. Tech. Rev. 3 (2010) 27-31.

44. B. Narayanasamy, S. Rajendran, Prog. Org. Coat. 67 (2010) 246-254.

45. S. Rajendran, P. Sumithra, B.S. Devi, J. Jeyasundari, Zastita Materijala 50 (2009) 223.

46. H. Benita Sherine, R.K Mani, S. Rajendran, “J. Electrochem. Soc. India 57 (2008) 67-73.

47. S. Rajendran, V. Uma, A. Krishnaveni, J. Jeyasundari, B. Shyamaladevi, M. Maivannan, Arabian J. Sci. Eng. 34 (2010) 147-158.

48. S.A. Kanimozhi, S. Rajendran, Arabian J. Sci. Eng. 35 (2009) 41-52.

49. R.J. Rathish, S. Rajendran, J.L. Christy, B.S. Devi, S. Johnmary, M. Manivannan, K. Rajam, P. Rengan, Open Corros. J. 3 (2010) 38-44. 
50. S. Rajendran, B.V. Apparao, N. Palanisswamy, Electrochim. Acta 44 (1998) 513.

51. S. Rajendran, B.V. Apparao, N. Palaniswamy, Anti-corrosion Methods 45 (1998) 338.

52. R.M.S. Francis, G.C. Bassler, T.C. Morrill, Spectrometric identification for organic compounds (New York, N.Y: John Wiley \& Sons, 1986.

53. I.Sekine, Y.Hirakawa, Corrosion 42 (1986) 272. 